\title{
Comparative assessment of coronary risk in HIV-infected patient cohort using Framingham index and Spanish validated coronary risk index: REGICOR
}

\author{
M Cervero Jiménez*, R Torres Perea, JL Agud Aparicio, JJ Jusdado Ruiz- \\ Capillas, C García Lacalle, M Álamo del Rodríguez and E García Benaya
}

Address: H. Severo Ochoa, Leganés. Madrid, Spain

* Corresponding author

from Ninth International Congress on Drug Therapy in HIV Infection

Glasgow, UK. 9-13 November 2008

Published: 10 November 2008

Journal of the International AIDS Society 2008, I I (SuppI I):P93 doi:I0.I I86/I758-2652-I I-SI-P93

This abstract is available from: http://www.jiasociety.org/content/II/SI/P93

(c) 2008 Jiménez et al; licensee BioMed Central Ltd.

\section{Purpose of the study}

Framingham risk index overestimates the probability of coronary heart disease (CHD) in populations with low incidence.

\section{Methods}

We estimated the 10-year coronary risk in a sample of Spanish outpatients in our HIV clinic, using the standard Framingham index and an index developed and validated in a population of Catalonia (Northern Spain): REGICOR. The following data were collected in all patients: age, gender, smoking status, HIV risk group, CD4+ cell count, HIV viral load, fasting glucose and insulin levels, lipid profile, blood pressure, waist circumference, BMI and present ART. We used the HOMA (homeostatic model assessment) index to assess insulin resistance, choosing as cut-off point, 3.8. The IDF (International Diabetes Foundation) criteria have been used to define increased waist circumference, hypertension, hypertrygliceridemia, low HDL-cholesterol and hyperglycemia.

\section{Summary of results}

128 outpatients seen in our clinic between January 1 and June 30,2007 , were included. Ninety-seven $(72 \%)$ were males, median age was 43 years and $37 \%$ had sexually transmitted HIV infection. At the time of the study median CD4+ cell count was 397 cells $/ \mu \mathrm{L}, 78 \%$ had a viral load below 50 copies/mL, and 118 were receiving HAART. $6.3 \%$ had diabetes and $28.9 \%$ arterial hypertension.
Median blood total cholesterol, HDL-cholesterol, LDL and triglycerides were $172.5 \mathrm{mg} / \mathrm{dL}, 42 \mathrm{mg} / \mathrm{dL}, 92 \mathrm{mg} / \mathrm{dL}$ and $134 \mathrm{mg} / \mathrm{dL}$, respectively. Forty-one percent were overweight, $20 \%$ had insulin resistance as estimated by HOMA and $51.6 \%$ fulfilled IDF criteria for abdominal obesity; $74.2 \%$ were current smokers. Using the REGICOR index, estimated 10-year CHD risk greater than 5\% was 3.3 times lower than by Framingham index (14.2\% vs. $46.9 \%)$. An estimated probability of CHD events over $15 \%$ in 10 years was five times lower using REGICOR index than with the standard Framingham index $(0.8 \%$ vs. $3.9 \%)$.

\section{Conclusion}

REGICOR index seems more accurate for the assessment of CHD risk in primary prevention in Spain, and presumably so in HIV-infected patients as well. It should be validated in other Spanish regions and specifically in HIVinfected patients. This would have an impact on therapeutic decisions.

\section{References}

I. Marrugat J, et al.: Coronary risk estimation in Spain using a calibrated Framingham function. Rev Esp Cardiol 2003, 56(3):253-6I. 